\title{
Action of phosphoric acid on cholestrine
}

\section{M.C. Zwenger}

To cite this article: M.C. Zwenger (1850) Action of phosphoric acid on cholestrine, Philosophical Magazine Series 3, 36:242, 246-247, DOI: 10.1080/14786445008646469

To link to this article: http://dx.doi.org/10.1080/14786445008646469

册 Published online: 30 Apr 2009.

Submit your article to this journal 중

Q View related articles $₫$ 
to one litre and a half of alcohol, than six times the quantity of cochineal.

Erythrosate of ammonia, after evaporating the excess of ammonia, possesses the same properties as the potash salt; but its colouring power is four times greater, and may be advantageously employed as red ink and for colouring soaps.

It appears that Russian rhubarb possesses the greatest colouring power, then Chinese, and lastly indigenous rhubarb; but the lastmentioned affords the most brilliant colour as a dye.-Journ. de Pharm. et de Chém., Janvier 1850.

\section{ACTION OF PHOSPHORIC ACID ON CHOLESTRINE. \\ BY M. C. ZWENGER.}

Cholestrine is readily decomposed by concentrated phosphoric acid. The products of this decomposition, like those obtuined by the action of stilphuric acid, are solid and well-defined carburetted hydrogens ; but by their physical properties they are clearly distinguished from those obtained with sulphuric acid.

When one part of cholestrine is treated with six or eight parts of concentrated phosphoricacid, and the mixture is evaporated till its temperature reaches $278^{\circ} \mathrm{F}$., the fusing point of cholestrine, this substance is completely decomposed. On the cooling of the fused mass, which must not have its temperature increased, a matter is obtained which has lost all crystalline appearance, and contains two carburetted hydrogens, cholesteron and cholestearon; these two carburets are separated by boiling alcohol, which dissolves the cholesteron. After purification by repeated crystallizations from absolute alcohol, this substance is obtained in brilliant rhombic prisms which fuse at $154^{\circ} \mathrm{F}$. At a higher temperature the cholesteron boils, and may be distilled almost unaltered. It burns with a sooty flame; nitric acid oxidizes it, and sulphuric acid renders it of a red colour. It is insoluble in water, slightly soluble in cold alcohol, more soluble in it when concentrated and boiling, and very soluble in æether. Its mean composition is-

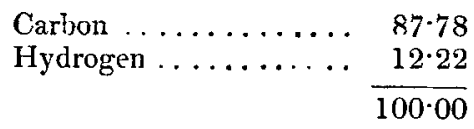

Cholestearon is obtained in boiling the residue which has been exhausted by alcohol in ather. By cooling and evaporation of the æthereal solution, the new carburetted hydrogen is deposited in the form of a crystalline mass, which is readily purified by repeated solution in æther.

Cholestearon crystallizes from its æthereal solution in white silky needles, forming an interwoven mass. It dissolves with difficulty in æther, very slightly in alcohol, and not at all in water. Its proper solvents are the fixed oils. It fuses at about $347^{\circ} \mathrm{F}$. At a higher temperature it distils, undergoing alteration. It burns with a sooty 
flame. Its composition is expressed by the following numbers :-

$$
\begin{array}{rr}
\text { Carbon } \ldots \ldots \ldots \ldots \ldots & 87 \cdot 76 \\
\text { Hydrogen } \ldots \ldots \ldots \ldots \ldots & 12.24 \\
100 \cdot 00
\end{array}
$$

It is consequently isomeric with cholesteron.-Journ. de Pharm. et de Chém., Novembre 1849.

\section{METEOROLOGICAL OBSERVATIONS FOR JAN. 1850.}

Chiswick.-January 1. Sharp frost: fine: cloudy. 2. Hazy: fine. 3. Foggy : hazy. 4. Foggy : overcast : clear. 5,6. Frosty : very fine : clear and frosty. 7. Sharp frost : clear: severe frost at night. 8. Frosty : overcast. 9. Slight fail of granular snow : overcast. 10. Snowing slightly: overcast 11. Hazy throughout. 12. Slight snow : dusky: hazy. 13. Hazy : clear and frosty. 14, 15. Cloudy and cold. 16,17. Densely overcast. 18. Foggy : snow at night, with heavy rain. 19. Cloudy : drizzly. 20. Frosty. 21. Cloudy. 22. Hazy. 23. Hazy : clear at night. 24. Fogrgy and drizzly. 25. Foggy : densely overcast : rain at night. 26. Densely clouded: showery. 27. Sudden rise of barometer : frosty : very fine. 28. Overcast. 29. Very fine: rain. 30 . Foggy : very fine. 31. Hazy and cold : heavy rain at night.

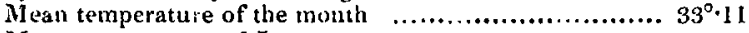

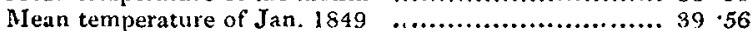

Mean temperature of Jan. for the last twenty-four years . $36 \cdot 60$

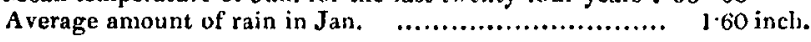

Boston.-Jan. I. Fine. 2. Cloudy. 3, 4 Cloudy : rain p.M. 5-8. Fine. 9-11. Cloudy. 12. Cloudy : snow a.m. 13. Fine. 14-17. Cloudy. 18. Cloudy : snow and rain P.M. 19. Cloudy : rain early A.s. 20. Cloudy : snow A.M. 21, 22. Cloudy. 23. Fine. 24. Cloudy. 25. Fine. 26. Cloudy: rain and snow r.m. 27. Fine. 28. Cloudy. 29, 30. Fine. 31. Fine: rain p.M.N.B. This has been the coldest January since the year 1838 .

Apllegarth Manse, Dumfries-shire.-Jan. 1. Irost : dull and threatening change. 2. Thaw : small rain. 3. Thaw : drizzle. 4. Slight frost early A.M.: rain and wind $\mathrm{l}$. .4 . 5. Snow half an inch deep : frost. 6. Frost very hard : snow lying. 7, 8. Frost very hard. 9. Frost very hard: thermometer $11^{\circ}$. 10. Cloudy, looking like change. 11. Cloudy, but still freezing. 12. Still slight frost, but unsettled. 13. Frost still slight : cloudy. 14. Frost, slight A.M. : harder P.M. 15. Bright and clear : hard frost : a little snow. 16. Frost : stight shower of snow : looking dull. 17. Hard frost : clear: snow lying. 18. Hard frost, and heavy snow 4 inches deep. 19. Fro t not so hard : thaw p.M. : frost again. 20. Frost: additional sprinkling of snow. 21. Frost hard again. 22. Frost moderate. 23. Thaw : mild : cloudy. 24. Thaw : snow melting fast. 25. Rain in the night: thaw continuing. 26. Thaw A.x.: came on to freeze at 6 P.M. 27. Hard frost A.M. : thaw and rain P.... 2R. Heavy rain: snow nearly gone. 29. Slight frost A.M. : keener P.M. 30. Frost moderate : snow all gone. 31. Slight shower of' snow A.M. : frost : rain P.it.

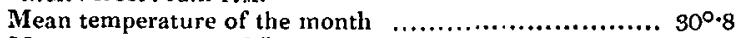

Mean temperature of Jan. 1849 ........................... $96 \cdot 3$

Mean temperature of $\mathrm{J}$ an. for the last twenty-eight years. $34 \cdot 9$

Average amount of rain in $J$ an. for the last twenty years. $2 \cdot 60$ inches.

Sandwick Manse, Orkney.-Jan. 1. Cloudy. 2. Bright : fine: rain. 3. Showers: sleet-showers. 4. Thunder : sleet-showers. 5. Thunder: showers, 6. Sleet-showers. 7. Sleet-showers : clear. 8. Cloudy. 9. Rain : cloudy. J0. Cloudy : sleet-showers. 11. Cloudy : clear. 12. Snow-showers: cloudy. 13. Cloudy: clear : frost : aurora. 14. Snow-showers: snow-drift. 15. Snow-drift. 16. Snow-drift: snow : thaw. 17. Rain : clear: frost: aurora. 18. Clear: frost: cloudy, I9. Snow-showers : cloudy: aurora. 20. Cloudy. 21. Cloudy : thaw. 22. Showers : drizzle. 23, 24. Drizzle. 25. Cloudy : snow-showers. 26. Snowshowers: snow : clear. 27. Snow : frost: snow-showers. 28. Showers : drizzle. 29. Bright: large halo. 30. Fine : frost : clear : aurora. 31. Bright : rain. 